\title{
OBSERVATIONS ON THE ULTRACENTRIFUGAL PATTERN OF SERUM PROTEINS IN RHEUMATOID ARTHRITIS
}

\author{
BY \\ LUIGI VILLA, ANGELO FASOLI, FRANCO SALTERI, AND \\ CAMILLO B. BALLABIO \\ Istituto di Clinica Medica della Università di Milano \\ (Direttore: Prof. L. Villa) \\ Centro Cardioreumatologico \\ (Dirigente: Prof. C. B. Ballabio)
}

Recent evidence has demonstrated that the serum protein alterations commonly present in rheumatoid arthritis, though following the general pattern of chronic infectious diseases (that is hypoalbuminaemia, hyperalpha- and hypergamma-globulinaemia), show some distinctive features that may be specific for this disease. The most evident among these features is the presence of globulins with a high sedimentation constant $\left(S_{\mathrm{w}, 20} \cong 22\right)$ (Franklin, Holman, Müller-Eberhard, and Kunkel, 1957; Kuhn, 1959); it is believed that the 22S fraction derives from the association of a globulin of the normal 7S class with a protein macromolecule (19S) that is responsible for the serological reactions termed collectively the rheumatoid factor (Franklin and Kunkel, 1958; Kunkel, Franklin, and MüllerEberhard, 1959; Vaughan, 1959). A close relation between the level of this component and the severity of the clinical picture has been observed (Franklin, Kunkel, and Ward, 1958; Kuhn, 1959). The exact significance of this fraction in the pathology of rheumatoid arthritis is still unknown; it has been suggested that it may play a role in determining vascular and perivascular lesions that are an essential feature of the disease (Christian, 1958; Epstein and Engleman, 1959); furthermore, its precipitation in tissues, as a consequence of an immunological reaction, may have a pathogenic role (Franklin, Kunkel, and Ward, 1958; Kunkel, 1959; Vaughan and Orbison, 1959). However, these hypotheses are far from being substantiated by direct evidence and a more detailed knowledge of the protein pattern in this disease seems to be necessary before an interpretation is attempted.

Data obtained in our Department (Salteri, Cirla, and Fasoli, 1960) in patients with acute exacerbations of rheumatoid arthritis corresponding to the picture of the "aggravation syndrome" that often develops after prolonged steroid treatment (Villa, Ballabio, and Sala, 1953; Ballabio and Grampa, 1960), may contribute to the characterization of the protein pattern of this disease.

\section{Material and Methods}

Fifteen patients with the clinical picture of rheumatoid arthritis according to current criteria have been studied: eleven showed the usual signs of the disease in its fully developed form and four presented the symptoms of the "aggravation syndrome".

Serum samples, obtained in the post-absorptive state, were diluted with normal saline to a protein content of 1-3 g. per cent. and analysed in the Spinco Model E Ultracentrifuge, at room temperature (about $20^{\circ}$ C.), at 52,640 r.p.m. Photographs were taken at $16-\mathrm{min}$. intervals after the rotor reached full speed. The pictures were enlarged and the areas of the various peaks determined with a planimeter. The $\mathbf{S}$ values were calculated according to the usual formula, by extrapolating to zero concentration the values observed for the same samples at various dilutions. 


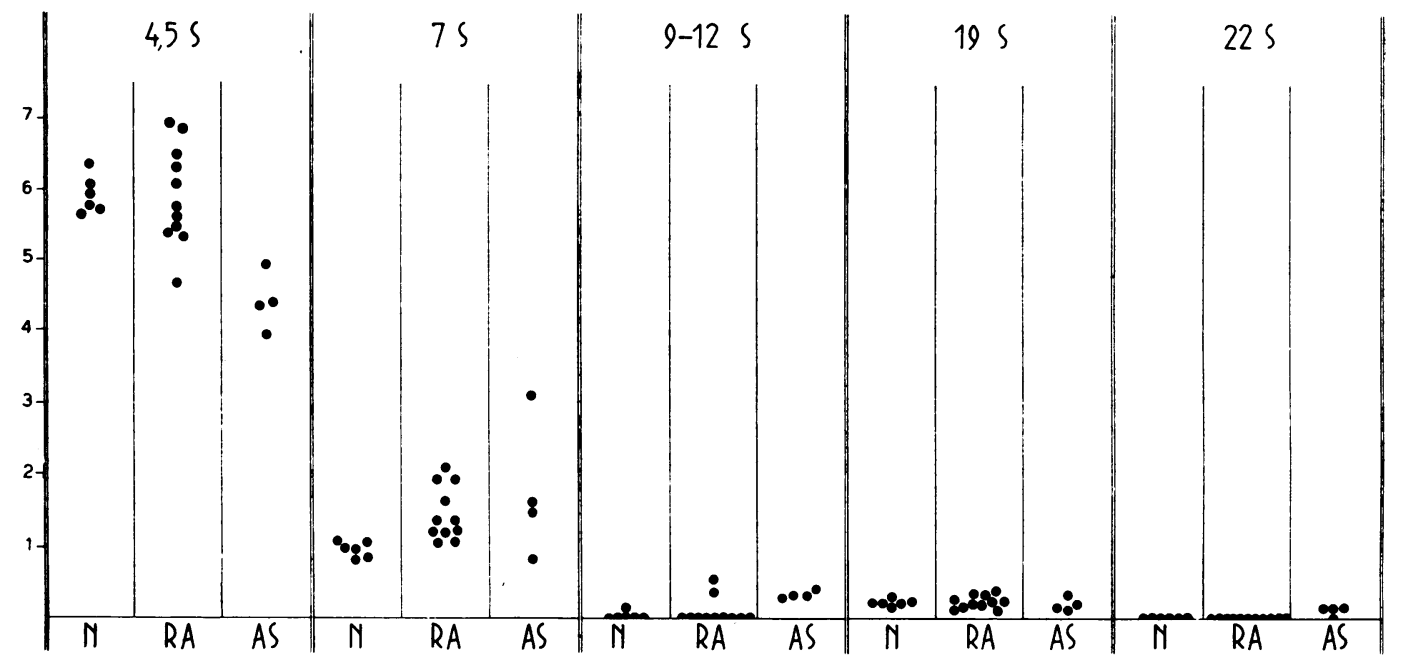

Fig. 1.-Ultracentrifugal serum protein fractions in normal subjects $(N)$ and in patients with rheumatoid arthritis in the typical form (R.A. and with the "aggravation syndrome" (A.S.).

\section{Results}

(A) Typical Rheumatoid Arthritis (Fig. 1)

The ultracentrifugal analysis of serum proteins does not show in most cases specific abnormalities: there is a moderate increase of the 7S fraction, and an inconstant tendency towards a diminution of the $4.5 \mathrm{~S}$ fraction, while the $19 \mathrm{~S}$ component is well within the normal range of variation. This picture corresponds, as a whole, to that of other chronic inflammatory diseases.

However, in two cases in this group another peak was present, close to the descending branch of the $7 \mathrm{~S}$ peak, that corresponded to an $\mathrm{S}$ value of $9-12$ and to a concentration of $0 \cdot 3-0 \cdot 5 \mathrm{~g}$. per cent. (Fig. 2, opposite). This component is not evident with this technique (or is present only in trivial amounts) in the rest of the sera of the group, and in the conditions involving hyperglobulinaemia that have been studied so far, with the exception of some cases of plasmocytoma.

\section{(B) Rheumatoid Arthritis with "Aggravation Syn-} drome" (Fig. 1)

The four cases in this group show a lower level of the $4 \cdot 5 \mathrm{~S}$ fraction than the preceding series, and no clear-cut differences exist with regard to the $7 \mathrm{~S}$ and 19S components. All show relatively large amounts of the 9-12S fraction $(0 \cdot 2-0 \cdot 5 \mathrm{~g}$. per cent.), and three also have a $22 \mathrm{~S}$ component of $0 \cdot 1-0 \cdot 15 \mathrm{~g}$. per cent. (Fig. 3, opposite).

In three cases the analysis was repeated 1 to 4 months later, after a period of treatment with high doses of ACTH and with prednisone at $\mathrm{a} \underset{\mathbb{D}}{\frac{\mathbb{D}}{O}}$ lower dose level than before admission. Two 3 patients experienced a marked clinical improvement $\mathbb{\Phi}$ and, at the same time, showed an amelioration $\overrightarrow{.}$ of the protein pattern-an increase of the $4 \cdot 30$ fraction and a decrease of the $7 \mathrm{~S}$ and $9-12 \mathrm{~S}$ fraetions; the $22 \mathrm{~S}$ component did not change to significant degree. The third patient did not improve either clinically or with regard to the serum $\overline{0}$ protein picture (Table).

$$
\text { TABLE }
$$

CHANGES IN THE ULTRACENTRIFUGAL SERUM PROTEIN

FRACTIONS IN THREE RHEUMATOID ARTHRITIC PATIENTS WITH "AGGRAVATION SYNDROME" AFTER TREATMENT WITH ACTH AND LOW DOSES OF PREDNISONE

\begin{tabular}{|c|c|c|c|c|c|c|}
\hline \multirow{2}{*}{ Case } & \multirow{2}{*}{ No. } & \multicolumn{5}{|c|}{ Protein Fractions (g. per cent.) } \\
\hline & & $4 \cdot 5 S$ & $7 \mathrm{~S}$ & $9-12 S$ & $19 \mathrm{~S}$ & $22 \mathrm{~S}$ \\
\hline \multirow{2}{*}{1} & Before & $4 \cdot 40$ & $1 \cdot 51$ & $0 \cdot 33$ & $0 \cdot 14$ & $0 \cdot 12$ \\
\hline & After & $4 \cdot 31$ & $0 \cdot 81$ & $0 \cdot 20$ & 0.07 & $0 \cdot 11$ \\
\hline \multirow{2}{*}{2} & Before & $4 \cdot 96$ & $1 \cdot 68$ & $0 \cdot 31$ & $0 \cdot 20$ & $0 \cdot 15$ \\
\hline & After & $5 \cdot 41$ & 0.85 & - & $0 \cdot 21$ & $0 \cdot 13$ \\
\hline \multirow{2}{*}{3} & Before & $4 \cdot 43$ & 0.86 & $0 \cdot 37$ & $0 \cdot 34$ & - \\
\hline & After & $4 \cdot 59$ & $0 \cdot 61$ & $0 \cdot 52$ & $0 \cdot 38$ & - \\
\hline
\end{tabular}

\section{Discussion}

Our data correspond in general to the results obtained by other authors: however, they differ $\stackrel{\mathcal{D}}{\rightarrow}$ in showing the occasional presence of a 9-12S $\mathrm{C}$ 


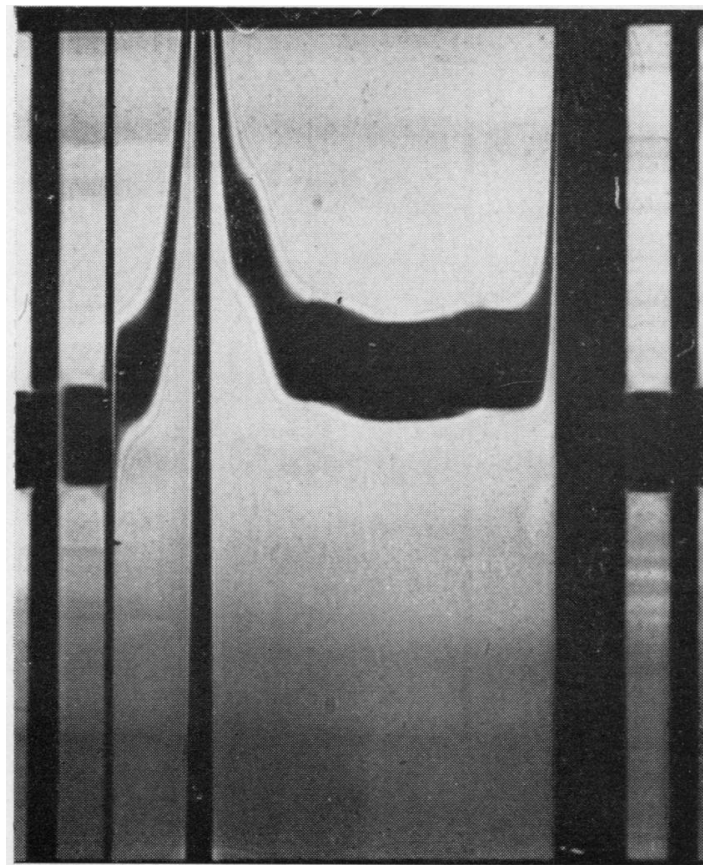

Fig. 2.-Photograph taken after $64 \mathrm{~min}$. ultracentrifugation at 52,640 r.p.m. (bar angle $70^{\circ}$ ) of the serum (diluted $1: 3$ with normal saline) of a patient with typical rheumatoid arthritis. The following peaks are visible from left to right: $4 \cdot 5 \mathrm{~S}, 7 \mathrm{~S}, 10 \mathrm{~S}$, and $19 \mathrm{~S}$.

fraction in patients with typical rheumatoid arthritis and in all cases of our series with the "aggravation syndrome". A fraction with similar sedimentation characteristics has been observed in trace amounts by Wallenius, Trautman, Kunkel, and Franklin (1957) in their ultracentrifugal studies of the electrophoretic components of normal human serum; it was seen that both the alpha 2 and beta globulins contained a small amount of material with an $\mathrm{S}$ value of 12. Christian (1959) has presented data suggesting that cold precipitates from rheumatoid arthritic sera may contain a component with an $S$ value between 7 and 19 .

Our data show that the level of the 9-12S component may be related to the severity of the rheumatoid arthritis symptoms, particularly in cases with the "aggravation syndrome".

In three of our cases a $22 \mathrm{~S}$ fraction was present; our data are not sufficient to rule out a possible relation between the level of this fraction and that of the 9-12S component; however, they suggest that this is not the case, though both changes are often present at the same time.

It is noteworthy, on the whole, that rheumatoid arthritis is associated with serum protein changes that are rarely, if ever, present in other related or

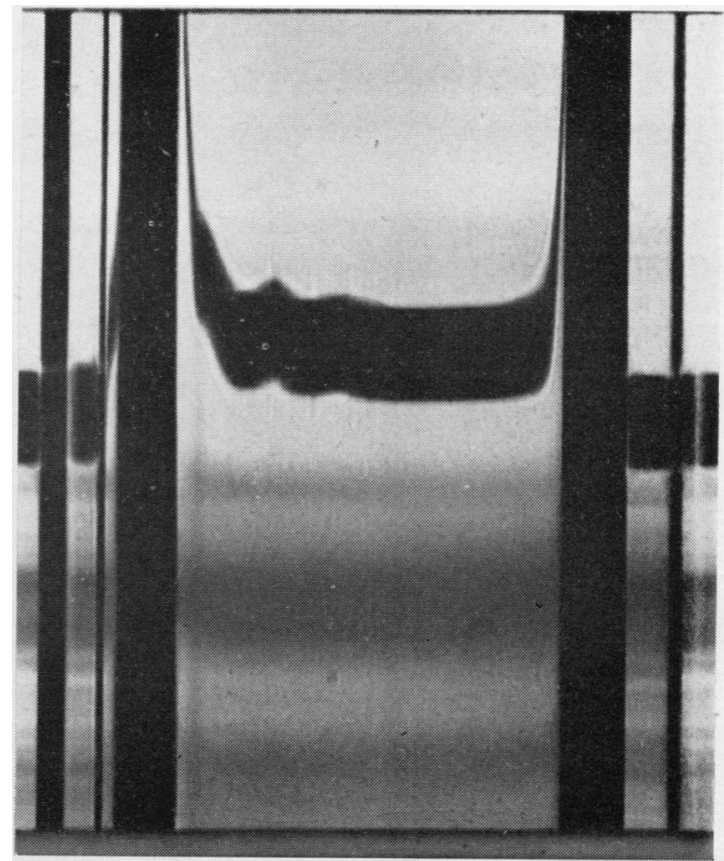

Fig. 3.-Photograph taken after $32 \mathrm{~min}$. ultracentrifugation at 52,640 r.p.m. (bar angle $70^{\circ}$ ) of the serum (diluted $1: 2$ with normal saline) of a patient with the "aggravation syndrome". On the descending branch of the main peak $(4 \cdot 5+7 \mathrm{~S})$ it is possible to recognize the $10 \mathrm{~S}$ component; to the right of this the $19 \mathrm{~S}$ and $22 \mathrm{~S}$ peaks are seen.

unrelated conditions; the presence in plasmocytoma or macroglobulinaemia of fractions having a sedimentation constant of the same order of magnitude as that of the two above-mentioned components observed in rheumatoid arthritis (9-12S and 22S) does not imply the chemical and/or biological identity of the fractions showing the same $S$ values.

The tendency of rheumatoid arthritic patients to build up protein components that differ in sedimentation rate (and therefore in molecular weight) from the normal may indicate either a derangement of serum protein synthesis or the interaction of normal protein with other substances or with one another so that a larger particle is formed. Some data suggest that the latter mechanism is possibly the one responsible.

No data are available on the origin of the 9-12S component of rheumatoid arthritis; the possibility that it may derive from the interaction of normal components cannot be ruled out. The fact that a fraction with similar characteristics has been shown to be present, in minimal amount, in normal sera would suggest that it is related to this normal component. Obviously new evidence is necessary to clarify this question. 


\section{Summary}

Ultracentrifugal analysis of serum proteins was performed in fifteen patients with rheumatoid arthritis. In eleven cases the disease had a typical course, and in four who had been treated with long-term steroid therapy the clinical picture of the so-called "aggravation syndrome" was present. In the former group the serum protein pattern showed a moderate rise of the $7 \mathrm{~S}$ fraction as the most constant abnormality; in two cases a peak in the 9-12S region was observed. In the latter group (those with the "aggravation syndrome") a consistent diminution of the $4.5 \mathrm{~S}$ fraction was recorded in addition to the rise of the $7 \mathrm{~S}$ fraction. The 9-12S peak was evident in all cases, of the "aggravation syndrome" and in three of them a $22 \mathrm{~S}$ component was also present.

The amelioration of the clinical picture was associated with a rise of the $4 \cdot 5 \mathrm{~S}$ fraction and a diminution of the $7 \mathrm{~S}$ and 9-12S components.

The possible meaning of these findings for the pathological physiology of rheumatoid arthritis is tentatively discussed.

\section{REFERENCES}

Ballabio, C. B. and Grampa. G. (1960). "Atti VII ${ }^{\circ}$ Giornate Reumatologiche Romane." (In the press.)

Christian, C. L. (1958). J. exp. Med., 108, 139.

(1959). Arthr. and Rheum., 2, 289.

Epstein, W. V. and Engleman, E. P. (1959). Ibid., 2, 250.

Franklin, E. C., Holman, H. R., Müller-Eberhard, H. J., and Kunkel, H. G. (1957) J. exp. Med., 105, 425 - (1958). Arthr. and Rheum., 1, 260.

- - - and Ward, J. R. (1958). Ibid., 1, 400.

Kuhn, W. J. (1959). Ibid., 2, 96.

Kuhn, W. J. (1959). Ibid., 2, 96.
Kunkel, H. G. (1959). Arch. intern. Med., 104, 832. Franklin, E. C., and Müller-Eberhard, H. J. (1959). J. clin. Invest., 38, 424.

Salteri, F., Cirla, E., and Fasoli, A. (1960). Reumatismo. (In the press.)

Vaughan, J. H. (1959). Amer. J. Med., 26, 596.

- and Orbison, L. J. (1959). Arthr. and Rheum., 2, 465.

Villa, L., Ballabio, C. B., and Sala, G. (1953). Reumatismo, 5 Suppl. to Fasc. No. 2 (Atti del Vi ${ }^{\circ}$ Congresso della Società italiana di Reumatologia, Taormina, 1952), p. 43

Wallenius, G., Trautman, R., Kunkel, H. G., and Franklin, E. C. (1957). J. biol. Chem., 225, 253.
Observations sur l'image ultracentrifuge des protéines du sérum dans l'arthrite rhumatismale

RÉSUMÉ

On analysa par centrifugation les protéines sériques de 15 malades atteints d'arthrite rhumatismale. Dans? 11 cas la maladie présentait une évolution typiquę mais chez 4 malades, traités pendant un temps prolong par des stéroïdes, il y avait un tableau clinique nomme "syndrome d'aggravation". Dans le premier groupe of nota une élévation modérée de la fraction 7S comme li plus constante anomalie; dans deux cas on observa un sommet dans la région 9-12S. Dans le deuxième groupes (celui avec la "syndrome d'aggravation") il y eut une diminution régulière de la fraction $4 \cdot 5 \mathrm{~S}$, en même temps qu'une augmentation de la fraction $7 \mathrm{~S}$. Le sommet 9-12S fut évident dans tous les cas de "syndrome d'aggravation" et dans trois d'entre eux il y eut aussi uñ composant $22 \mathrm{~S}$.

Une amélioration du tableau clinique fut associée une élévation de la fraction $4 \cdot 5 \mathrm{~S}$ et une baisse des com posants $7 \mathrm{~S}$ et $9-12 \mathrm{~S}$.

On discute tentativement la possible importance di్ట్ ces données dans la physiopathologie de l'arthrite rhumatismale.

\section{Observaciones sobre el proteinograma sérico por ultracentifugación en la artritis reumatoide} Sumario

Se realizó un análisis por ultracentrifugación de las proteinas séricas de 15 enfermos con artritis reumatoideø্ঠ En once casos la enfermedad presentaba un curso típico ${ }_{2}$ $\mathrm{y}$ en cuatro enfermos, tratados durante un largo tien@o con esteroides, estaba presente un cuadro clínico द्le\$ llamado "síndrome de agravación". En el primer grifo se notó una moderada elevación de la fracción $7 \mathrm{~S}$ comb la anormalidad más constante; en dos casos se observi una cima en la zona 9-12S. En el segundo grupథ̣ (aquél con "síndrome de agravación") se presentó unł coherente disminución de la fracción $4 \cdot 5 \mathrm{~S}$, al mismo tiempo que la elevación de la fracción $7 \mathrm{~S}$. La cim\$ 9-12S fué evidente en todos los casos con "síndrome de agravación" y en tres de ellos un componente $22 \mathrm{~S}$ estuvQ presente también.

La mejoría del cuadro clínico se vió asociada con unج్ج elevación de la fracción 4.5S y una disminución de loవ̣. componentes $7 \mathrm{~S}$ y $9-12 \mathrm{~S}$.

Se discute tentativamente el posible significado de esto hallazgos en la fisiopatologia de la artritis reumatoide. 